\title{
PERANAN KEPEMIMPINAN DAN BUDAYA ORGANISASI TERHADAP PERILAKU KARYAWAN
}

\author{
Artikel
}

Untuk memenuhi tugas mata kuliah Psikologi Manajemen

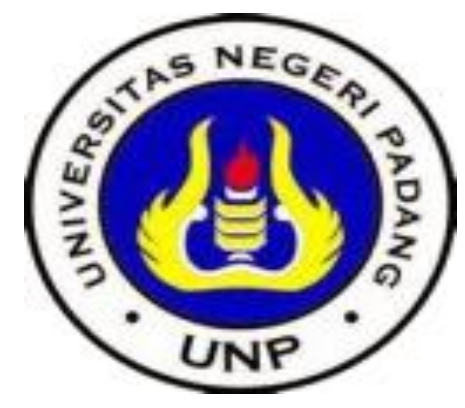

Disusun oleh:

PUTRI BESTARI

17002098

Dosen Pembina : Dra. Ermita M.Pd.

JURUSAN ADMINISTRASI PENDIDIKAN

FAKULTAS ILMU PENDIDIKAN

UNIVERSITAS NEGERI PADANG

2019 


\title{
Artikel
}

\section{PERANAN KEPEMIMPINAN DAN BUDAYA ORGANISASI TERHADAP PERILAKU KARYAWAN}

\author{
Putri Bestari \\ 17002098 \\ Jurusan Administrasi Pendidikan \\ Universitas Negeri Padang \\ Sumatera Barat, Indonesia \\ E-mail: putribestari19@gmail.com
}

\begin{abstract}
Abstrak.
Budaya organisasi dirasakan sebagai suatu yang harus tumbuh dalam membentuk perilaku organisasi, perilaku karyawan didalamnya dan membentuk citra organisasi pada masyarakat sebagai pemakai jasa atau produknya. Tujuan artikel ini adalah untuk mengetahui gambaran budaya organisasi yang dikembangkan oleh pemimpin dan peranan pemimpin dalam mengembangkan budaya organisasi untuk mencapai tujuan organisasi serta perilaku karyawan. Peranan pemimpin dalam mengembangkan budaya organisasi terletak pada komunikasinya dan sebagai role modelling. Komunikasi yang ada di dalam organisasi merupakan bagian penting yang harus diperhatikan pemimpin, karena komunikasi merupakan alat bagi pemimpin untuk menjalankan budaya yang diharapkan. Sebagai role modelling, pimpinan perusahan cukup baik, karena setiap karyawan mempunyai perilaku dan persepsi mengenai pimpinan sebagai panutan. Penulis menyarankan agar sebaiknya kedisiplinan karyawan yang sudah terbangun dengan baik hendaknya selalu dipelihara dengan jalan selalu mengadakan pemantauan dan tentunya dengan sanksi apabila terjadi pelanggaran.
\end{abstract}

Kata Kunci : Peranan Pemimpin, Budaya Organisasi Dan Perilaku Karyawan 


\section{Pendahuluan}

Kemampuan atau kecakapan pemimpin merupakan tulang punggung organisasi, mereka membuat perubahan, memajukan dan mendorong organisasi untuk mencapai hasil semaksimal mungkin. Pemimpin juga harus mengembangkan budaya organisasi yang dapat menunjang pencapaian visi dan misi organisasi yang telah ditetapkan. Budaya organisasi yang dimaksud adalah pola perilaku yang meliputi pemikiran, tindakan, bahasa dan kebiasaan yang dilakukan oleh anggota organisasi atau karyawan dalam organisasi, nilai-nilai yang dibagi atau dirasakan bersama oleh anggota suatu organisasi, norma-norma, kepercayaan, asumsi -asumsi para anggota organisasi untuk mengelola masalah dan pengaruh di sekitarnya. Budaya organisasi akan berfungsi sebagai penjamin kelangsungan hidup organisasi apabila dalam organisasi tersebut terdapat nilainilai fundamental organisasi yang baik seperti menjunjung tinggi nilai kejujuran dan integritas, penghargaan atas disiplin, pelayanan yang prima dan penghormatan atas keterbukaan.

Budaya organisasi dapat terlaksana dengan baik, apabila pemimpin mampu menjalankan fungsinya sesuai dengan perannya, artinya bahwa peranan pemimpin dapat mempengaruhi, menggerakkan dan mengarahkan bawahan supaya perilaku anggota sesuai dengan aturan yang telah ditetapkan yang akan berdampak terbentuknya budaya organisasi.

\section{Pembahasan}

\section{A. Pengertian Pemimpin}

Pemimpin adalah seorang pribadi yang memiliki kecakapan dan kelebihan khususnya kelebihan kecakapan di satu bidang, sehinngga dia mampu mempengaruhi orang-orang lain untuk bersama-sama melakukan aktivitasaktivitas tertentu, demi pencapaian satu atau beberapa tujuan (Kartono, 2005: 51). Sedangkan menurut Matondang (2008: 5) Pemimpin yaitu seseorang yang mampu mempengaruhi orang lain untuk melakukan atau tidak melakukan sesuatu yang diinginkan sesuai yang diinginkan. Berdasarkan beberapa pengertian di atas, maka dapat disimpulkan bahwa pemimpin adalah orang yang mempunyai kemampuan 
dalam mempengaruhi, menggerakkan dan mengarahkan orang lain (anggota) untuk melakukan usaha bersama ke arah pencapaian tujuan organisasi.

\section{B. Pengertian Pemimpin}

Seorang pemimpin dalam menjalankan tugasnya maka harus selalu berpikir kreatif dan penuh dengan ide-ide baru, pemimpin harus mengkomunikasikan ide tersebut kepada anggotanya dan mempengaruhi anggota untuk dapat menerima ide tersebut dan melaksanakannya sesuai dengan perilaku organisasi yang diinginkan oleh pemimpin sehingga tujuan organisasi dapat dicapai.

\section{Fungsi Pemimpin}

Fungsi seorang pemimpin menurut Kartono, (2005: 93) adalah memandu, menuntun, membimbing, membangun, memberi atau membangun motivasimotivasi kerja, mengemudikan organisasi, menjalin jaringan-jaringan komunikasi yang baik, memberikan supervisi atau pengawasan yang efisien, dan membawa para pengikutnya kepada sasaran yang ingin dituju sesuai dengan ketentuan waktu dan perencanaan. Berdasarkan uraian tersebut dapat disimpulkan bahwa fungsi pemimpin yaitu mengkoodinasikan anggota yang dipimpinnya agar rencana yang telah diketahui dapat dicapai dengan baik. Namun lebih jauh dari itu yang terpenting adalah adanya kesiapan dan kekuatan serta sikap mental yang baik sehingga bisa memimpin secara adil dan bijaksana.

\section{Peranan Pemimpin}

Mintzberg dalam Thoha (2010: 12 -20) mengemukakan tiga peran utama yang dimainkan oleh setiap pimpinan dimanapun hirarkinya. Dari tiga peran utama kemudian diperinci menjadi sepuluh peranan lainnya yaitu:

1. Peranan hubungan antarpribadi (Interpersonal Role)

a) Peranan sebagai figurehead, yakni suatu peranan di dalam setiap kesempatan dan persoalan yang timbul secara normal.

b) Peranan seagai pemimpin (leader), dalam peranan ini pemimpin melakukan hubungan interpersonal dengan yang dipimpin, dengan 
melakukan fungsi-fungsipokoknya diantaranya memimpin, memotivasi, mengembangkan, dan mengendalikan.

c) Peranan sebagai pejabat perantara (liaison manager), di sini pimpinan yang berintegrasi dengan teman sejawat, staf, dan orang lain yang berada di luar organisasinya, untuk mendapat informasi yang diperlukan.

2. Peranan yang berhubungan dengan informasi (Informational Role)

Peranan ini meletakkan pimpinan pada posisi yang unik dalam mendapatkan informasi. Pemimpin mencari informasi di luar lingkungan dan sebagai pusat informasi bagi organisasinya. Peranan ini terdiri dari perananperanan sebagai berikut:

a) Peranan sebagai monitor, peranan ini mengidentifikasi seorang pemimpin sebagai penerima dan pengumpul informasi, supaya pemimpin mampu untuk mengembangkan suatu pengertian yang baik dari organisasi yang dipimpinnya, dan mempunyai pemahaman yang komplit tentang lingkungannya.

b) Peranan sebagai disseminator, peranan ini melibatkan pemimpin untuk menangani proses transmisi dari informasi-informasi ke dalam organisasi yang dipimpinnya.

c) Peranan sebagai juru bicara (spokesman), peranan ini dimainkan pemimpin untuk menyampaikan informasi ke luar lingkungan organisasinya. Bedanya dengan disseminatorialah spokesman ini memberikan informasi ke luar lingkungan, sebaliknya dengan disseminator memberikan informasi ke dalam lingkungan organisasi.

3. Peranan pembuat keputusan (Decisional Role)

Peranan ini membuat pemimpin harus terlibat dalam suatu proses pembuatan strategi di dalam organisasi yang dipimpinnya. Proses pembuatan strategi ini secara sedarhana dinamakan sebagai suatu proses yang menjadikan keputusan-keputusan organisasi dibuat secara signifikan dan berhubungan. Ada empat peranan yang dikelompokkan ke dalam pembuatan keputusan adalah sebagai berikut: 
a) Peranan sebagai entrepreneur, dalam peranan ini pemimpin bertindak sebagai pemrakarsa dan perancang dari banyak perusahaan -perusahaan yang terkendali dalam organisasi.

b) Peranan sebagai penghalau gangguan (disturbance handler), peranan ini membawa pemimpin untuk bertanggung jawab terhadap organisasi ketika organisasinya terancam bahaya, misalnya akan dibubarkan, terkena gosip, isu-isu kurang baik, dan sebagainya.

c) Peranan sebagai pembagi sumber (resource allocator), di sini pemimpin diminta memainkan peranan untuk memutuskan ke mana sumber dana akan didistribusikan ke bagian-bagian dari organisasinya.

d) Peranan sebagai negosiator, peranan ini meminta kepada pemimpin untuk aktif berpartisipasi dalam arena negosiasi.

\section{E. Pengertian Budaya Organisasi}

Budaya organisasi adalah suatu sistem pengertian bersama yang dipegang oleh anggota-anggota suatu organisasi, yang membedakan organisasi tersebut dari organisasi lainnya (Robbins dan Judge, 2008: 256). Menurut Griffin, (2004: 162) budaya organisasi adalah serangkaian nilai, keyakinan, perilaku, kebiasaan, dan sikap yang membantu seseorang anggota organisasi dalam memahami apa yang dianut organisasi tersebut, bagaimana organisasi tersebut melakukan segala sesuatu, dan apa yang dianggapnya penting.

Berdasarkan pendapat tersebut dapat disimpulkan bahwa budaya organisasi merupakan pola perilaku yang meliputi pemikiran, tindakan, bahasa, dan kebiasaan yang dilakukan oleh anggota suatu organisasi yang membedakan organisasi tersebut dari organisasi lainnya, nilai-nilai yang dibagi atau dirasakan bersama oleh anggota suatu organisasi, normanorma, kepercayaan dan asumsi-asumsi para anggota organisasi untuk mengelola masalah dan pengaruh di sekitarnya.

\section{F. Karakteristik Budaya Organisasi}

Karakteristik budaya organisasi adalah karakteristik yang telah umum disetujui untuk merefleksikan budaya organisasi, yaitu aturan perilaku yang 
diamati, norma-norma organisasi, nilai-nilai yang dominan yang terdapat dalam organisasi, filosofi yang dianut oleh organisasi, peraturan-peraturan organisasi, dan iklim organisasi.

Gambaran ini menjadi dasar bagi sikap pemahaman bersama yang dimiliki oleh para anggota organisasi. Pemahaman tersebut mengenai organisasi, cara bagaimana menyelesaikan permasalahan yang ada di dalam organisasi dan perilaku yang diharapkan dari anggota.

Menurut (Ermita, 2012) Loyalitas pegawai yang tinggi dapat dilihat dari tingkah lakunya (pegawai) yang selalu melaksanakan tugas, menghormati atasan dan sesama teman, mematuhi dan melaksanakan peraturan serta giat dalam berbagai kegiatan kantor. Pegawai yang loyal terhadap tugas maupun terhadap kantor (organisasinya) akan selalu mendahulukan kepentingan tugas dan organisasi di atas kepentingan pribadinya.. Pegawai yang memiliki loyalitas tersebut di atas, pegawai yang tidak selalu mengutamakan yang akan diperoleh, tetapi tetap mengabdi dengan penuh pengabdian dan keikhlasan.

\section{G. Perilaku karyawan}

Berbagai tindakan yang dilakukan oleh seseorang tentunya dilakukan untuk memenuhi keinginan dan kebutuhannya. Dalam memenuhi kebutuhannya, seseorang akan berperilaku yang berbeda-beda antara orang yang satu dengan yang lainnya. Perilaku seorang pekerja adalah komplek sebab akan dipengaruhi oleh berbagai variabel individu misalnya kecakapan, kepribadian, persepsi dan pengalamannya. Hersey dan Blanchard (1992:15); perilaku pada dasarnya berorientasi tujuan. Dengan kata lain perilaku pada umumnya dimotivai oleh keinginan untuk memperoleh tujuan tertentu. Perilaku yang terjadi didalam organisasi hakekatnya adalah interaksi diantara individu yang ada. Mengingat setiap individu memiliki karakter yang berbeda-beda, maka sebaiknya pimpinan mengetahui masing-masing latar belakang bawahannya dalam memberikan dukungan kepada organisasi. Perilaku seseorang juga akan dipengaruhi karakteristik dari organisasi yang bersangkutan, oleh karena itu harus diarahkan sesuai dengan tujuan organisasi. Dalam kenyataannya kadang-kadang perilaku seseorang bertolak belakang dengan tuntutan yang ada, hal ini karena adanya 
perbedaan persepsi dalam menjalankan aktivitas yang dilakukan. Menurut Arnold Feldman (1986:24); menemukakan sebagai berikut: Perilaku individu berkenaan dengan tindakan yang nyata, dilakukan seseorang. Bagaimana tidak, dalam kenyataannya kumpulan dari perilaku atau tindakan merupakan perbuatan yang bergantung apakah organisasi mengharapkan atau meminta kepada seseorang. Contoh lain faktor yang mempunyai pengaruh terhadap perilaku individu adalah organisasi, motivasi, kemampuan, persepsi, kepribadian, sistem orgainsasi dan sumber-sumbernya.

Perilaku timbul karena adanya ketidak seimbangan atau ketidaksesuian pada struktur kognitif yang dihasilkan oleh persepsi seseorang terhadap lingkungan yang ada. Jadi perilaku merupakan fungsi dari pernyataan-pernyataan masa saat ini dari sistem kognitif yang ada pada diri seseorang tanpa memperhatikan bagaimana pernyataan tersebut dapat berada dalam suatu sistem. Ditinjau dari sifatnya perbedaan perilaku manusia dapat disebabkan oleh keinginan, kebutuhan, cara berfikir, pengalaman dan reaksi afektifnya.

1. Tentang pengetahuan (knowledge)

Merupakan faktor yang dapat mempengaruhi perilaku seseorang makin tinggi pengetahuan seseorang tentunya makin terarah perilaku yang muncul dalam dirinya. Makna tentang pengetahuan adalah berhubungan dengan segenap apa yang kita ketahui baik secara formal maupun informal. Menurut Suria Sumantri (1993:104); pengetahuan pada hakekatnya merupakan segenap apa yang kita ketahui tentang obyek tertentu, termasuk kedalamannya yaitu ilmu, jadi ilmu merupakan bagian dari pengetahuan yang diketahui oleh manusia disamping berbagai pengetahuan lainnya seperti seni dan agama. Pada umumnya apabila pengetahuan yang dimiliki oleh seseorang cukup tinggi maka penguasaan pekerjaan yang menjadi tanggung jawabnya dapat diselesaikan dengan baik.

2. Ketrampilan (Skill)

Keterampilan sebagai penggerak aktivitas atau ketika kemampuan cenderung digunakan untuk berfikir dan skill diukur dalam bentuk masalah keseksamaan

yang jelas dalam kinerja tugas. Pada diri seseorang akan memiliki berbagai ketrampilan antara lain: technical skill, human skill, conceptual skill. Pada 
kegiatan sehari-hari ketiga jenis ketrampilan tersebut tidak merata dan cenderung kesalah satu dari ketiga ketrampilan yang paling dominan bagi seseorang. Seorang pimpinan mempunyai kewajiban mengembangkan skill bawahannya sesuai dengan tuntutan pekerjaan.

\section{Sikap (Attitude)}

Sikap seseorang dipelajari pada suatu periode waktu dan diorganisir oleh pengalaman dan menimbulkan pengaruh tertentu terhadap perilaku seseorang. Sikap dapat dipelajari dan dengan sikap yang dimiliki oleh seseorang, maka yang bersangkutan dapat memberikan penilaian terhadap lingkungan dan hubungan antar pribadi. Sikap dapat bertahan atau berubah tergantung dari stimulus yang ada, sikap merupakan bagian yang intrinsik dari personality of person's. Sikap merupakan ciri dari reaksi terhadap obyek atau situasi yang didasarkan kepada pengalaman dan peran perilaku khusus atau ungkapan dari pendapat yang pasti. Jadi sikap akan ditempa oleh pengalaman dan peran seseorang dalam berbagai situasi yang mereka hadapi. Mengingat didalam sikap mengandung unsur kognitif maka ada nilai yang merupakan constellation atau kumpulan dari suka atau tidak suka, pandangan dan penilaian-penilaian yang rasional maupun tidak rasional. Dengan menggunakan nilai yang dimiliki, sikap terhadap suatu obyek akan mendekati suatu kebenaran atau bahkan merupakan suatu alat untuk memperoleh hasil yang optimal.

\section{Kemampuan (ability)}

Kemampuan seseorang berbeda-beda hal ini disebabkan oleh banyak faktor yang mempengaruhi. Seorang manajer harus mampu melihat kemampuan yang dimiliki oleh bawahannya sehingga dapat dimanfaatkan seefektif mungkin. Robbins (1996:82); ability (kemampuan) merupakan kapasitas seorang invidu untuk mengerjakan berbagai tugas dalam suatu pekerjaan. Pada dasarnya seseorang mempunyai kemampuan intelektual dan fisik, oleh karena itu tugas seorang manajer harus dapat menyeimbangkan kemampuan intelektual dan fisik yamg dimiliki oleh bawahannya. Kinerja karyawan akan tercapai dengan baik apabila pada saat rekrutmen dapat diidentifikasi kemampuan yang sebenarnya dimiliki oleh calon tenaga kerja. Permasalahan yang utama adalah bagaimana 
seorang manajer dapat menempatkan seseorang pada jenis pekerjaan yang sesuai dengan kemampuannya.

Menurut (Ermita \& Anisah, 2013) Disiplin merupakan ketaatan dan tepatan suatu aturan yang dilakukan secara sadar tanpa adanya dorongan atau paksaan pihak lain. Menurut Anoraga (2006:46) "disiplin adalah suatu sikap, perbuatan untuk selalu mentaati tata tertib”. Sedangkan Nitisemito (1982:99) mengemukakan bahwa: "disiplin adalah suatu sikap tingkah laku dan perbuatan yang sesuai dengan peraturan dari organisasi, baik yang tertulis maupun yang Sedangkan disiplin kerja merupakan perluasan dari disiplin yang dikaitkan dengan tugas seorang guru. Sebagaimana yang dikemukakan Muhlisin (2009) bahwa: Disiplin kerja guru adalah suatu keadaan tertib dan teratur yang dimiliki guru dalam bekerja di sekolah, tanpa ada pelanggaran-pelanggaran yang merugikan baik secara langsung maupun tidak langsung terhadap dirinya, teman sejawatnya dan terhadap sekolah secara keseluruhan. Berdasarka “'”n pendapat di atas dapat disimpulkan bahwa dalam melaksanakan tugasnya, guru dituntut untuk memiliki disiplin kerja yang tinggi. Disiplin guru dapat tercermin dalam ketepatan dan ketaatan guru dalam melaksanakan tugasnya.

\section{H. Fungsi Budaya Organisasi terhadap perilaku karyawan}

Budaya suatu organisasi tidak selalu mudah dipahami, tidak konkrit dan sering hanya dinyatakan secara implisit, setiap organisasi menciptakan serangkaian asumsi, kesepakatan dan norma-norma yang mengatur perilaku para anggotanya sehari-hari.

Perilaku yang sesuai dengan budaya organisasi akan berakibat tidak hanya pengakuan atas keberadaan seseorang sebagai anggota, tetapi juga mendapatkan imbalan dan penghargaan. Sebaliknya, perilaku yang dinilai negatif, karena tidak sesuai dengan budaya organisasi, dikenakan sanksi dapat berupa pengakhiran keberadaan seseorang dalam organisasi yang bersangkutan. Itulah sebabnya ditekankan bahwa seseorang diterima dan diakui sebagai anggota organisasi, yang bersangkutan harus siap dan bersedia melakukan berbagai penyesuaian dalam sistem nilai, sikap, kebiasaan dan perilakunya (Siagian, 1998: 249 -250). Kesimpulanfungsi budaya organisasi adalah sebagai perekat sosial di dalam 
mempersatukan anggota-anggotanya dalam tujuan organisasi berupa ketentuanketentuan atau nilai yang harus dilakukan oleh para anggota.

\section{Peranan Pemimpin dalam Mengembangkan Budaya Organisasi serta perilaku karyawan}

Budaya organisasi dapat terlaksana dengan baik, apabila pemimpin mampu menjalankan fungsinya sesuai dengan peranannya, artinya bahwa peranan pemimpin dapat mempengaruhi, menggerakkan dan mengarahkan bawahannya supaya perilaku bawahan sesuai dengan aturan yang telah ditetapkan akan membantu terbentuknya budaya organisasi. Dalam mengembangkan budaya organisasi seorang pemimpin harus mempunyai nilai dan kepercayaan yang jelas dan kuat tentang organisasi yang diinginkan. Pemimpin memiliki kontribusi sebagai pencipta dan membentuk budaya organisasi, karena memiliki kemampuan dan kekuasaan untukmelakukannya. Selain itu, pemimpin memiliki visi dan misi, kemudian memberikan contoh dan menyebarkannya yang kemudian diikuti oleh bawahannya. Hubungan yang saling terbuka dan percaya merupakan hal yang mendukung penyebaran nilai-nilai dan norma yang ada dalam budaya organisasi.

Peranan pemimpin dalam mengembangkan budaya organisasi tercermin pada integrasi satu sama lain dengan menggunakan bahasa dan tata cara yang berlaku, adanya norma-norma yang berlaku seperti standar dan ketentuan perilaku, termasuk petunjuk tentang pekerjaan yang harus dilaksanakan, nilai-nilai penting yang hendak ditanamkan, dibangun, dan diresapi bersama oleh segenap anggota. Misalnya kualitas pelayanan, efesiensi, dan lain-lain, adanya filsafat tentang kebijakan-kebijakan yang mencerminkan kepercayaan organisasi tentang bagaimana memperlakukan pegawai dan pelanggan, peraturan-peraturan tentang petunjuk bagaimana bergaul dengan organisasinya, serta iklim organisasi yang memuat tentang cara berinteraksi antar anggota, danpola bertindak terhadap orang luar. Budaya organisasi memberikan anggota organisasi cara-cara atau pola berperilaku, berpikir serta menuntut para anggota organisasi dalam mengambil keputusan. Apabila pemimpin membentuk budaya, maka mereka tidak membentuknya berdasarkan pilihan sendiri, melainkan melalui interaksi terusmenerus dengan anggota organisasi yang lain. Ini berarti seorang pemimpin harus 
mempunyai kemampuan komunikasi strategis dan dasar power yang kuat (Kertahadi, 2003: 32). 


\section{KESIMPULAN}

Dalam mengarahkan perilaku karyawan terhadap aktivitas yang dilakukan diperlukan seorang pimpinan yang dapat mengakomodir berbagai karakteristik yang dimiliki oleh bawahannya. Mengingat masing-masing individu dalam berperilaku cenderung akan dipengaruhi oleh stimulus yang ada dalam lingkungannya maka sedini mungkin semua karyawan harus mengetahui tentang visi dan misi perusahaan. Visi dan misi perusahaan merupakan arah dalam mencapai tujuan perusahaan. Budaya organisasi sebagai pedoman berperilaku bagi semua anggota organisasi harus disosialisasikan sedini mungkin sejak karyawan pertama kali masuk menjadi anggota organisasi sampai pada waktu pemisahaan dari perusahaan. Pada umumnya karyawan dalam berperilaku hanya berdasarkan kepada habits (kebiasaan-kebiasaan) yang dianggap benar dan disepakati seara bersama dalam bentuk peraturan. Budaya organisasi merupakan basic assumptions (asumsi-asumsi dasar) yang harus diyakini dan dimengerti oleh semua angota organisasi dalam melakukan semua aktivitasnya (mulai dari pimpinan sampai dengan strata karyawan yang terbawah) 


\section{DAFTAR PUSTAKA}

Ermita. (2012). hubungan antar manusia dan semangat kerja pegawai. Pedagogi, Junal Ilmiah Ilmu Pendidikan, XII(2), 70-81. Retrieved from http://ejournal.unp.ac.id/index.php/pedagogi/article/view/2200

Ermita, \& Anisah. (2013). Pembinaan Dan Kinerja Guru Sekolah Menengah Atas Negeri (Sman). Pedagogi, XIII(2), 81-92. Retrieved from http://ejournal.unp.ac.id/index.php/pedagogi/article/viewFile/4285/3353

Davis, Keith and W.Newstrom (1999). Perilaku Dalam Organisasi. Edisi Ketujuh Terjemahan. Erlangga. Jakarta

Gitosudarmo, Indriyo; Sudita, Nyoman (2000). Perilaku Organisasi. BPFE Yogyakarta

Hersey, Paul and Blanchard, Ken (1996). Manajemen Perilaku Organisasi, Pendayagunaan Sumber Daya Manusia Edsisi Bahasa Indonesia. Jakarta. Penerbit Erlangga.

Musselman, Vernon A \& Jackson, John H. (1990). Pengantar Ekonomi Perusahaan. Edisi Kesembilan. Terjemahan. Penerbit Erlangga. Jakarta

Nimran, Umar (2004). Perilaku Organisasi. CV.Citra Media Surabaya.

Robbins, Stephen P. (1994). Teori Organisasi, Struktur, Desain \& Aplikasi Edisi Bahasa Indonesia. Alih bahasa Yusuf Udaya Lic.Ec, Jakarta ARCAN.

Suriasumantri, Jujun S (1993). Filsafat Ilmu Sebuah Pengantar Populer. Cetakan ke VII. Jakarta: Karya Uni Press.

Susanto, AB (1997). Budaya Perusahaan. Manajemen dan Persaingan Bisnis. Elex Media Komputindo. Jakrta

Wahyuningsih, Tri (2001). Dampak Pergantian Pimpinan Pada Kinerja Organisasi. Jurnal Administrasi dan Bisnis Vol 1, No. 2 Hal. 29-42 